\title{
Genotyping of the polymorphism within exon 1 of Hormone Sensitive Lipase (LIPE) Gene in three Chinese Yak (Bos grunniens) breeds by PCR-RFLP (Brief Report)
}

\section{Genotypisierung eines Polymorphismus im Exon 1 des Genes für die hormonsensitive Lipase bei drei chinesischen Yak (Bos grunniens) Rassen mittels PCR-RFLP (Brief Report)}

ZHIJIE MA ${ }^{1}$, JINCHENG ZHONG ${ }^{2}$, JINGTAO XU' and YAPING WEI ${ }^{1}$

'Academy of Animal Science and Veterinary Medicine, Qinghai University, Xining, People's Republic of China, ${ }^{2}$ College of Life Science and Technology, Southwest University for Nationalities, Chengdu, People's Republic of China

\section{Background}

The yak (Bos grunniens), a herbivore living on the Qinghai-Tibetan Plateau and its adjacent territories, is one of world's most remarkable domestic animals. Over the past decades, research has been done on properties of yak meat at physiological and biochemical levels. In recent years, some candidate genes associating with meat quality and lipid metabolism in yak have been studied (MA et al. 2007, ZHONG et al. 2007). The Hormone Sensitive Lipase (LIPE) gene has been regarded as a candidate gene associating with lipid metabolism and meat quality. Several studies have reported the genetic variations in the LIPE genes of human and pig (TALMUD et al. 1998, KNOLL et al. 1998, WU et al. 1998, HARBITZ et al. 1999), whereas the yak LIPE gene polymorphism has not been investigated and no information is available. The aim of this study was to identify and characterize the genetic variation in Chinese yak LIPE at the DNA sequence level and genotyping of the polymorphism within LIPE in different yak breeds.

\section{Procedures}

\section{Primer sequences}

The primer sequences were adapted from those used by KNOLL et al. (1998) to match porcine LIPE gene sequence (acc. no. AJ000482 and AJ224692).

Forward primer: 5'-CGC ACA ATG ACA CAG TCG GT-3';

Reverse primer: 5'-CAG GCA GCG GCC GTA GAA GCA-3'.

\section{$P C R$ condition, PCR-RFLP and sequencing}

DNA was isolated from blood samples of 92 domestic yaks (31 Jiulong yaks, 31 Bazhou yaks and 30 Maiwa yaks) using a phenol-chloroform extraction protocol followed by an ethanol precipitation step. The PCR reaction mixture contained 50-100 ng yak genomic DNA, 10 pM of each primer, 0.50 U ExTaq DNA polymerase (TakaRa, Dalian, China), 10 XExTaq Buffer ( $\mathrm{Mg}^{2+}$ Free), $0.25 \mathrm{mM}$ dNTP, $2.5 \mathrm{mM} \mathrm{MgCl}_{2}$ and $\mathrm{ddH}_{2} \mathrm{O}$ in a final volume of 
$25 \mu \mathrm{L}$. The following cycles were applied: $95^{\circ} \mathrm{C} / 4 \mathrm{~min}$, followed by 35 cycles at $95^{\circ} \mathrm{C} / 45 \mathrm{sec}$, $60.5^{\circ} \mathrm{C} / 1 \mathrm{~min}, 72^{\circ} \mathrm{C} / 1 \mathrm{~min}$, and final synthesis at $72^{\circ} \mathrm{C} / 5 \mathrm{~min}$. The $13 \mu \mathrm{L} \mathrm{PCR}$ amplified product was incubated at $30^{\circ} \mathrm{C}$ for $5-8 \mathrm{~h}$ with $1 \mu \mathrm{L}$ of $S m a l(12 \mathrm{U} / \mu \mathrm{L}$ ) (TakaRa, Dalian, China), $2 \mu \mathrm{L}$ of 10×T Buffer (330 mM Tris-Ac, PH7.9; 100 mM Mg-Ac; 5 mM Dithiothreitol; 660 mM K-Ac), $0.1 \% \mathrm{BSA}$ and $\mathrm{ddH}_{2} \mathrm{O}$, respectively. The fragments were separated and visualized by electrophoresis in $2 \%$ agarose gels. The different genotypes were scored manually by comparison with a 150 bp DNA ladder (TakaRa, Dalian, China). Chi-square tests were conducted to test the population for Hardy-Weinberg equilibrium. After PCR-Smal analysis purified PCR products from homozygous individuals were sequenced directly with the ABI-3730 automatic DNA sequencer (Applied Biosystems). The sequences alignments, translations, and comparisons were carried out with Bioedit 4.8.10 soft.

\section{Results}

The restriction digestion of 498 bp PCR products with Smal enzyme revealed three genotypes $A A, A B$, and $B B$ (Table 1). Comparing the sequences from different homozygous individuals showed a G>A substitution at position nt70 (acc. no. AY871311 and AY898615). The single nucleotide polymorphisms (SNP) is in exon 1 of yak LIPE and results in an amino acid exchange $(\mathrm{G} \rightarrow \mathrm{R})$ (aa27 of the bovine sequence, acc. no. NP_001073689) (Figure 1).

Allele A was most frequent in all three breeds. Animals homozygote for the allele B were not obtained in Jiulong and in Maiwa, but only in Bazhou yaks. The Chi-square test results ( 1 degree of freedom, $P \leq 0.01$ ) revealed genetic equilibrium in three yak breeds.

Table1

Different genotypes and allele frequencies and corresponding fragment sizes after digestion of a $498 \mathrm{bp}$ $\mathrm{PCR}$ product with $\mathrm{Smal}$ restriction enzyme

Genotypen, relative Häufigkeiten der Allele und Fragmentgrößen nach Restriktionsverdau des 498 bp PCR Produkts mit Smal

\begin{tabular}{lccclcc}
\hline \multirow{2}{*}{ Breeds } & \multirow{2}{*}{ Animals } & \multicolumn{3}{c}{ Number (frequencies) of genotypes* $^{*}$} & \multicolumn{2}{c}{ Allele frequencies } \\
& & AA & AB & \multicolumn{1}{c}{ BB } & A & B \\
\hline Jiulong & 31 & $26(0.839)$ & $5(0.161)$ & 0 & 0.92 & 0.08 \\
Maiwa & 30 & $17(0.567)$ & $13(0.433)$ & 0 & 0.78 & 0.22 \\
Bazhou & 31 & $14(0.452)$ & $16(0.516)$ & $1(0.032)$ & 0.71 & 0.29 \\
\hline
\end{tabular}

* corresponding fragments obtained in PCR-RFLP, AA 333 bp, 96 bp, 69 bp, AB 402 bp, 333 bp, 96 bp, 69 bp, BB 402 bp, $96 \mathrm{bp}$

\section{Acknowledgements}

This study was funded by the Young and Middle-aged Scientific Research Fund Project of Qinghai University (No.2008-QN-11) and International Scientific and Technological cooperation project of National Science and Technology Ministry (No. 2008DFA31100). 


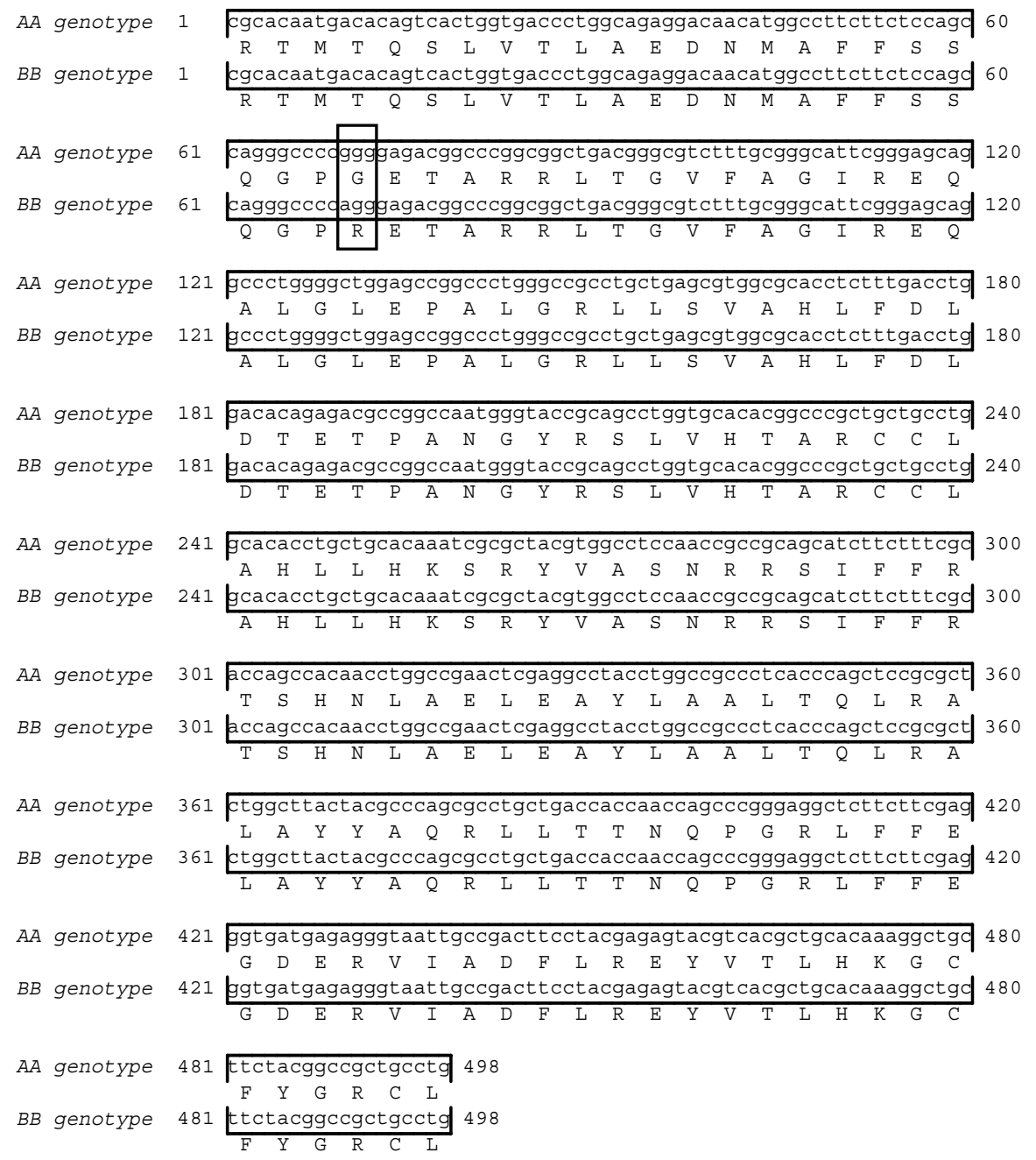

Figure 1

Sequences alignment of the yak LIPE gene variants A and B with the GenBank sequence AY871311 and AY898615

Sequenzalignment der LIPE Genvarianten A und B des Yaks mit den Genbanksequenzen AY871311 und AY898615

\section{References}

Harbitz I, Langset M, Ege AG, Høyheim B, Davies W (1999) The porcine hormone-sensitive lipase gene sequence structure polymorphisms and linkage mapping. Anim Genet 1, 10-5

Knoll A, Stratil A, Nebola M, Cepica S (1998) Chrachaterization of a polyorphism in exon 1 of the porcine hormone-sensitive lipase (LIPE) gene. Anim Genet 6, 462-3

Ma ZJ, Zhong JC, Chen ZH, Liu L, Chang HH, Luo XL (2007) Sequence variation and molecular evolution of hormone-sensitive lipase genes in species of Bovidae. J Genet Genom 1, 26-34

Talmud PJ, Palmen J, Walker M (1998) Identification of genetic variation in the human hormone-sensitive lipase gene and $5^{\prime}$ sequences homology of $5^{\prime}$ sequences with mouse promoter and identification of potential regulatory elements. Biochem Biophys Res Commun 3, 661-8 
Wu ZF (1998) Study on HSL and LPL genes as candidate genes of pig lipase deposite traits. Wuhan Docterss dissertation of Huazhong Agricultural University [in Chinese, English abstract]

Zhong JC, Ma ZJ, Ou JT, Zhu X, Liu SG (2007) Cloning and sequencing of GH, H-FABP and HSP72 genes in yak. Can J Anim Sci 4, 503-10

Received 30 September 2008, accepted 18 February 2009.

Corresponding author:

ZHIJIE MA

email: maziwise2004@yahoo.com

Insitute of Animal Science, Qinghai Academy of Animal Science and Veterinary Medicine, No. 1 Weier Road, Bio-Science Industrial District, Xining, Qinghai, People's Republic of China 